\title{
ANALISIS HUBUNGAN RESILIENSI MATEMATIK TERHADAP KEMAMPUAN PEMECAHAN MASALAH SISWA PADA MATERI LINGKARAN
}

\author{
Sri Maharani ${ }^{1}$, Martin Bernard ${ }^{2}$ \\ ${ }^{1}$ Program Studi Pendidikan Matematika. Fakultas Pendidikan Matematika dan Sains \\ ${ }^{1.2}$ Ikip Siliwangi Bandung \\ 1'maharanikth@gmail.com, ${ }^{2}$ pamartin23rnard@gmail.com
}

\begin{abstract}
The purpose of this study to determine the relationship of mathematical resilience to students problem solving abilities. This research was conducted in MTs Negeri Kota Cimahi class VIII-I even semester in academic year 2017-2018. The method used is qualitative descriptive method. Population taken is all students of class VIII MTs Negeri Kota Cimahi. Sampling using purposive sampling technique, which is a determination and sampling technique determined by the researchers with certain considerations. The sample consists of 34 students. Circle material used in research. Research instrument as many as 5 items about problem solving and resilience statement scale as many as 40 statement. The conclusion gained is that there are difficulties experienced by students in solving problem solving problem and there is correlation between mathematical resiliency to student problem solving ability equal to 0,649 .
\end{abstract}

Keywords: Problem Solving Ability, Mathematical Resilience

\begin{abstract}
Abstrak
Tujuan dari penelitian ini untuk mengetahui hubungan resiliensi matematik terhadap kemampuan pemecahan masalah siswa. Penelitian ini dilaksanakan di MTs Negeri Kota Cimahi kelas VIII-I semester genap pada tahun ajaran 2017-2018. Metode yang digunakan adalah metode deskriptif kualitatif. Populasi yang diambil adalah seluruh siswa kelas VIII MTs Negeri Kota Cimahi. Pengambilan sampel menggunakan teknik purposive sampling, yaitu suatu teknik penentuan dan pengambilan sampel yang ditentukan oleh peneliti dengan pertimbangan tertentu. Sampel terdiri dari 34 orang siswa. Materi lingkaran yang digunakan dalam penelitian. Instrumen penelitian sebanyak 5 butir soal pemecahan masalah dan skala pernyataan resiliensi sebanyak 40 pernyataan. Kesimpulan yang diperoleh yaitu terdapat kesulitan yang dialami siswa dalam menyelesaikan soal pemecahan masalah serta terdapat hubungan antara resiliensi matematik terhadap kemampuan pemecahan masalah siswa sebesar 0,649.
\end{abstract}

Kata Kunci: Kemampuan Pemecahan Masalah, Resiliensi Matematik

How to cite: Maharani, S. Bernard, M. (2018). Analisis Hubungan Resiliensi Matematik terhadap Kemampuan Pemecahan Masalah Siswa pada Materi Lingkaran. JPMI - Jurnal Pembelajaran Matematika Inovatif, 1 (5), 819-826.

\section{PENDAHULUAN}

Bernard (2015) Mata pelajaran Matematika perlu diberikan kepada seluruh peserta didik, dimulai dari sekolah dasar hingga jenjang sekolah yang lebih tinggi untuk membekali peserta didik dengan kemampuan berpikir logis, sistematis, analitis, kritis, dan kreatif, serta kemampuan bekerja sama. Menurut Hidayat \& Sariningsih (2018) mengatakan bahwa Dalam pembelajaran matematika pemecahan masalah merupakan inti pembelajaran yang merupakan 
kemampuan dasar dalam proses pembelajaran. Sedangkan Menurut Aripin (Alifah \& Aripin, 2018) menerangkan bahwa berpikir merupakan sebuah tindakan yang tidak gegabah dalam menyelesaikan suatu masalah serta menggunakan akal rasional dalam menentukan keputusan. Tujuan pembelajaran matematika salah satunya adalah untuk mengasah cara berpikir dan bernalar peserta didik dalam menarik kesimpulan serta mampu mengungkapkan pendapatnya dengan percaya diri dan kejujuran yang timbul dari peserta didik untuk memecahkan masalah yang dihadapi.

Pada saat ini pembaharuan pendidikan yang dicanangkan adalah dengan pembaharuan pola pikir masyarakat dimana pembelajaran selalu terpusat pada guru. Menurut Sani (Maryam, Nurdiawan, Hermawan, Purwasih, \& Rohaeti, 2018) bahwa pemerintah dan pihak terkait memberlakukan kurikulum 2013 dimana dalam kuikulum 2013 ini terdapat tiga aspek hasil belajar yaitu: (1)Kognitif; (2) Afektif; dan (3) Psikomotorik. Dengan adanya ke tiga aspek tersebut, berperan aktif merupakan tuntutan untuk siswa dalam proses pembelajaran. Salah satunya yaitu pembelajaran matematika didalam pendidikan. Hal ini sejalan dengan (Bernard, 2014) yang menyatakan bahwa peran yang sangat penting untuk generasi sekarang adalah kualitas pendidikan, yang berperan sebagai modal untuk memajukan negara.

Hudojo (Amir, 2015) mengungkapkan untuk mempersiapkan dan menjadikan para ahli ilmu pengetahuan serta teknologi bahkan sampai kepada ahli perencanaan kota merupakan salah satu fungsi pendidikan matematika yang tak dapat dipungkiri. Pernyataan tersebut menunjukkan pentingnya pembelajaran matematika untuk diajarkan dengan melalui penguasaan matematika dapat menghasilkan siswa yang berkompeten dalam menghadapi perubahan zaman. Oleh karena itu jenjang pendidikan awal adalah sekolah dasar, maka sangat penting pembelajaran matematika di sekolah dasar untuk diperhatikan agar tidak terjadi masalah-masalah lebih lanjut. Pemerintah Indonesia menekankan bahwa pembelajaran matematika hendaknya mengarah pada pemecahan masalah serta kemampuan pemecahan masalah bagi siswa.

Dahar (Sundayana, 2016) mengemukakan bahwa, pemecahan masalah merupakan kegiatan manusia yang memadukan beberapa konsep serta aturan yang pernah diperoleh sebelumnya, dan tidak sebagai suatu keterampilan generik. Sedangkan Hudojo (Sundayana, 2016) berpendapat bahwa, pemecahan masalah merupakan proses penerimaan masalah sebagai tantangan. Pemecahan masalah merupakan hal yang penting untuk belajar matematika. Dengan terbiasanya siswa dihadapkan dengan masalah yang dihadapi, maka siswa tersebut akan terbiasa menggunakan pola pikirnya sehingga dapat membantu keberhasilan orang tersebut dalam memecahkan kehidupan sehari-hari.

Pemecahan masalah diartikan sebagai suatu proses kegiatan aktif yang meliputi metode dan strategi siswa dalam menyelesaikan masalah sampai menemukan jawaban yang benar atau sesuai. Persoalan yang disajikan dalam pemecahan masalah yaitu persoalan non rutin yang tidak sering dijumpai dan itu merupakan hal yang baru bagi siswa. Dengan hal ini berarti tujuan pembelajaran matematika untuk meningkatan kemampuan pemecahan masalah siswa sudah tercapai. Hal serupa diungkapkan oleh Bernard, Nurmala, Mariam, \& Rustyani (2018) bahwa pemecahan masalah merupakan strategi pembelajaran yang melibatkan siswa aktif secara optimal yang memungkinkan siswa untuk melakukan eksplorasi, observasi, eksperimen, dan investigasi.

Adapun indikator kemampuan pemecahan masalah yang dipakai pada penelitian menurut Sumarmo (Husna, Ikhsan, \& Fatimah, 2013) sebagai berikut: “(1) mengidentifikasi unsurunsur yang diketahui dan ditanyakan, serta kecukupan unsur, (2) menerapkan strategi untuk 
menyelesaikan masalah didalam/diluar matematika, (3) menjelaskan/menginterpretasikan hasil sesuai permasalahan awal, (4) memeriksa kebenaran solusi, (5) menggunakan matematika secara bermakna".

Salah satu materi yang bersangkutan dengan kehidupan sehari-hari adalah lingkaran. Siswa dilatih untuk memecahkan suatu permasalahan yang mempunyai kaitan dengan luas dan keliling lingkaran, misalnya siswa diberi suatu permasalahan bagaimana mengetahui jumlah luas papan kayu yang dibutuhkan untuk menutup sebuah sumur. Materi lingkaran tercakup dalam ruang lingkup aspek geometri yang dipelajari pada kelas VIII. Saat penelitian berlangsung, ada beberapa siswa mengalami kesulitan dalam menyelesaikan soal pemecahan masalah. Kesulitan tersebut membuat peserta didik merasa takut dan menghindar dari kegiatan yang berkaitan dengan pemecahan masalah yang penuh dengan tantangan. Untuk mengatasi rasa cemas, siswa perlu memiliki sikap tekun, gigih, dan percaya diri yang biasanya disebut dengan resiliensi.

Masten et. al. (Hendriana, Rohaeti, \& Sumarmo, 2017) mendefinisikan resiliensi sebagai suatu proses dalam, kapasitas untuk, atau hasil dari usaha adaptasi terhadap kondisi yang menantang atau menakutkan. Secara lebih spesifik, resiliensi merupakan proses dimana seseorang mampu meraih keberhasilan atau kesuksesan dengan cara beradaptasi meskipun berada dalam keadaa penuh tantangan yang berisiko tinggi dan dalam situasi yang menakutkan.

Adapun indikator resiliensi yang digunakan dalam penelitian ini menurut Sumarmo (Hendriana et al., 2017) sebagai berikut : “(a)menunjukkan sikap tekun, yakin/percaya diri, bekerja keras dan sulit untuk menyerah dalam menghadapi masalah, kegagalan, dan ketidak pastian; (b)menunjukkan keinginan bersosialisasi, memiliki jiwa penolong, berdiskusi dengan sebayanya, dan beradaptasi dengan lingkungan sekitarnya; (c)memunculkan ide/pemikiran baru dan mencari solusi yang kreatif dengan tantangan; (d)kegagalan dijadikan pengalaman untuk membangun motivasi diri; (e)memiliki rasa ingin tahu, merefleksi, meneliti, dan memanfaatkan beragam sumber; (f)memiliki kemampuan mengontrol diri, sadar akan perasaannya".

Berdasarkan uraian di atas, maka rumusan masalah yang akan diajukan sebagai berikut (1) Apa penyebab kesulitan-kesulitan siswa dalam menyelesaian soal pemecahan masalah pada materi lingkaran ? Dan (2) Adakah hubungan antara resiliensi matematik terhadap kemampuan pemecahan masalah siswa?

\section{METODE}

Penelitian ini dilakukan pada semester genap tahun akademik 2017-2018 di kelas VIII-I MTs Negeri Kota Cimahi. Prosedur penelitian ini mempunyai 3 tahap yaitu perencanaan, pelaksanaan, pengumpulan data dan pelaporan. Pada tahap awal perencanaan kegiatan, hal yang dilakukan yaitu menyusun instrumen tes kemampuan pemecahan masalah,menyusun instrumen non tes resiliensi, serta melakukan uji instrumen. Selanjutnya pada tahap pelaksaan kegiatan yang dilakukan yaitu siswa diberi tes kemampuan pemecahan masalah dan setelah itu mengisi angket resiliensi yang telah disiapkan. Kemudian pada tahap pelaporan melakukan pengumpulan data dari angket dan instrumen tes yang diperoleh selama penelitian berlangsung serta pengolahan data dan kemudian dibuat laporan.

Metode yang digunakan yaitu metode deskriptif kualitatif. Pengambilan sampel pada penelitian ini adalah purposive sampling. Teknik Purposive sampling adalah suatu teknik 
penentuan dan pengambilan sampel yang ditentukan oleh peneliti dengan pertimbangan tertentu (Sugiyono, 2015). Pertimbangan-pertimbangan yang dilakukan dalam teknik purposive sampling ini bisa beragam dan bergantung pada kebutuhan dari penelitian yang akan dilakukan. Sampel penelitian terdiri dari 34 orang siswa.

Penelitian mempunyai tujuan untuk melihat penyebab kesulitan siswa dalam menyelesaikan soal pemecahan masalah serta mengetahui hubungan antara resiliensi matematik terhadap kemampuan pemecahan masalah siswa. Untuk melihat kesulitan siswa teknik analisis data dilakukan secara deskriptif, yaitu dengan mendeskripsikan lembar jawaban siswa. Sedangkan untuk mengetahui hubungan antara resiliensi matematik terhadap kemampuan pemecahan masalah dilakukan uji normalitas data dan uji korelasi.

\section{HASIL DAN PEMBAHASAN}

\section{Hasil}

Hasil penelitian berupa data diperoleh dari pemberian soal pemecahan masalah dan skala pernyataan resiliensi matematik kepada siswa kelas VIII di MTs Negeri Kota Cimahi. Sampel penelitian terdiri dari 34 orang siswa. Untuk mengetahui hubungan resiliensi matematik terhadap kemampuan pemecahan masalah dilakukan uji normalitas data dengan menggunakan SPSS 23 seperti di bawah ini :

Tabel 1. Hasil Uji Normalitas

\begin{tabular}{|l|r|r|r|r|r|r|}
\hline & \multicolumn{3}{|c|}{ Kolmogorov-Smirnov $^{\text {a }}$} & \multicolumn{3}{|c|}{ Shapiro-Wilk } \\
\cline { 2 - 7 } & Statistic & \multicolumn{1}{c|}{$\mathrm{df}$} & \multicolumn{1}{c|}{ Sig. } & \multicolumn{1}{c|}{ Statistic } & \multicolumn{1}{c|}{ df } & \multicolumn{1}{c|}{ Sig. } \\
\hline $\begin{array}{l}\text { kemampuan pemecahan } \\
\text { masalah }\end{array}$ &, 107 & 34 &, $200^{*}$ &, 945 & 34 &, 086 \\
resiliensi &, 138 & 34 &, 100 &, 947 & 34 &, 099 \\
\hline
\end{tabular}

Jika sig > 0,05 maka data berdistribusi normal, sedangkan jika sig $<0,05$ data tidak berdistribusi normal. Dilihat dari tabel di atas (Kolmogorov-Smirnov) signifikansi yang diperoleh 0,200 dan 0,100, sehingga data berdistribusi normal. Selanjutnya dilakukan uji korelasi untuk mengetahui apakah terdapat hubungan antara resiliensi matematik dan kemampuan pemecahan masalah siswa.

Hipotesis :

$\mathrm{H}_{0}$ : Tidak terdapat hubungan antara resiliensi matematik terhadap kemampuan pemecahan masalah siswa.

$\mathrm{H}_{\mathrm{a}}$ : Terdapat hubungan antara resiliensi matematik terhadap kemampuan pemecahan masalah siswa.

Kriteria korelasi $\alpha=0,05$

Jika sig $>0,05$ maka $\mathrm{H}_{0}$ diterima

Jika sig < 0,05 maka $\mathrm{H}_{0}$ ditolak

Tabel 2. Hasil Uji Korelasi

\begin{tabular}{|c|c|c|c|}
\hline & & $\begin{array}{c}\text { kemampuan } \\
\text { pemecahan } \\
\text { masalah }\end{array}$ & resiliens \\
\hline $\begin{array}{l}\text { kemampuan pemecahan } \\
\text { masalah }\end{array}$ & $\begin{array}{l}\text { Pearson Correlation } \\
\text { Sig. (2-tailed) } \\
\mathrm{N}\end{array}$ & 1 & $\begin{array}{r}.649^{11} \\
, 000 \\
34 \\
\end{array}$ \\
\hline resiliensi & $\begin{array}{l}\text { Pearson Correlation } \\
\text { Sig. (2-tailed) } \\
\mathrm{N}\end{array}$ & $\begin{array}{r}.649^{* x} \\
.000 \\
34\end{array}$ & 34 \\
\hline
\end{tabular}


Dari tabel di atas, $\mathrm{N}$ menunjukkan jumlah sampel sebanyak 34. Sedangkan hubungan korelasi (pearson correlation) ditunjukkan oleh angka $0,649(* *)$. Hal ini berarti terdapat korelasi yang signifikan antara resiliensi matematik dan kemampuan pemecahan masalah siswa adalah sebesar 0,649. Angka sig. (2-tailed) adalah 0,000 $<0,05$ maka $\mathrm{H}_{0}$ ditolak, sehingga dapat disimpulkan bahwa terdapat hubungan antara resiliensi matematik terhadap kemampuan pemecahan masalah siswa.

Kesulitan-kesulitan siswa dalam menyelesaikan soal pemecahan masalah dapat dideskripsikan dengan melihat lembar jawaban siswa sebagai berikut (Basuki, 2012):

Indikator soal nomor 1 : Mengidentifikasi unsur-unsur yang diketahui, yang ditanyakan, dan kecukupan unsur yang diperlukan.

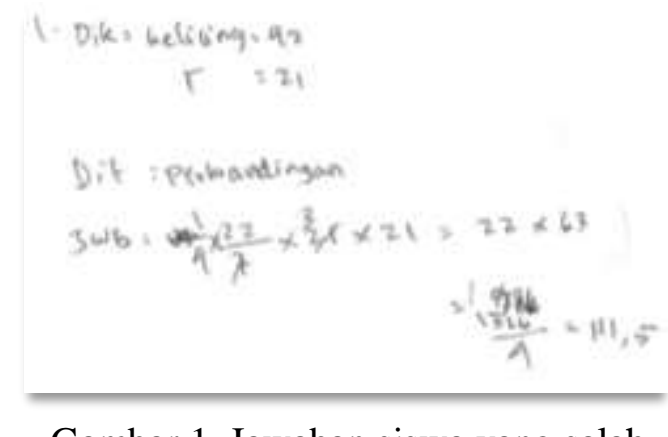

Gambar 1. Jawaban siswa yang salah

Berdasarkan gambar 1 di atas, siswa sudah dapat menjawab soal untuk indikator yang telah ditentukan baik siswa yang memiliki kemampuan tinggi dan rendah sekalipun. Tapi bagi siswa yang memiliki kemampuan rendah dia bisa menjawab dan mengidentifikasi unsur-unsur dari persoalan yang diberikan hanya saja siswa belum bisa menentukan strategi yang tepat untuk menyelesaikan persoalan yang diberikan dan kurangnya penguasaan konsep terhadap materi yang diujikan. Sehingga untuk indikator tersebut untuk siswa yang memiliki kemampuan rendah belum bisa menyelesaikan secara tepat.

Gambar 2. Jawaban siswa yang benar 
Berdasarkan gambar 2 di atas, siswa yang memiliki kemampuan tinggi secara prosedural dia sudah mampu mengerjakan soal yang diberikan. Hanya saja kurang teliti dan masih rendah dalam perhitungan, sehingga mengakibatkan jawaban yang seharusnya benar menjadi salah. Hal tersebut terjadi karena kurangnya pengetahuan materi prasyarat pada siswa. Sehingga untuk siswa yang memiliki kemampuan tinggi, indikator tersebut sudah bisa tercapai karena siswa bisa mengerjakan tapi belum bisa secara sempurna.

Indikator soal nomor 3 : Menjelaskan atau menginterprestasikan hasil sesuai permasalahan awal

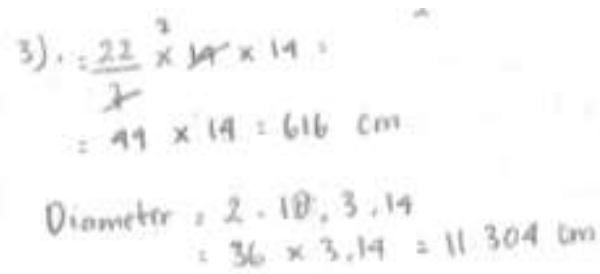

Gambar 3. Jawaban siswa yang salah

Berdasarkan gambar 3 di atas, siswa yang memiliki kemampuan rendah sudah mencoba menentukan strategi untuk persoalan yang diberikan tapi strategi yang digunakan kurang tepat. Siswa hanya mengisi dengan strategi yang menurutnya sesuai dengan persoalan namun tidak memikirkan strategi yang benar-benar tepat. Hal ini dikarenakan kurangnya penguasaan mengenai materi yang diujikan. Sehingga untuk indikator tersebut belum tercapai oleh siswa yang memiliki kemampuan yang rendah.
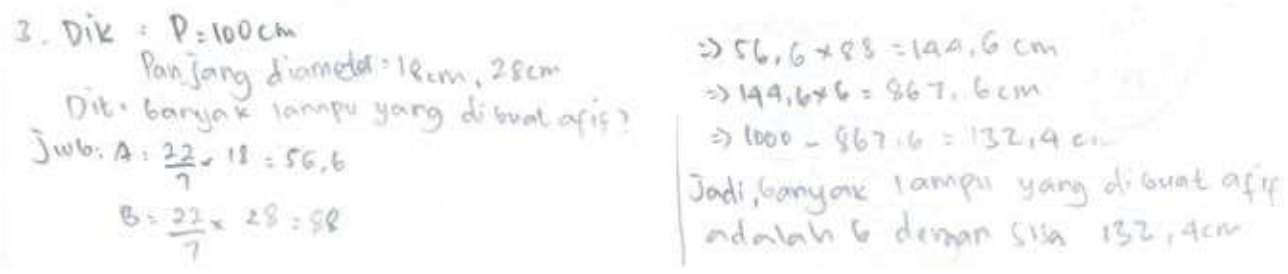

Gambar 4. Jawaban siswa yang benar

Berdasarkan gambar 4 di atas jawaban siswa sudah tepat. Siswa dapat menyelesaikan persoalan pemecahan masalah dengan menggunakan strategi yang sesuai secara prosedural. Hanya saja siswa langsung mengisi tidak disertai rumus terlebih dahulu. Hal ini membuktikan bahwa siswa sudah sangat menguasai materi dan siswa sudah memenuhi prasyarat dari materi yang diujikan dan siswa memiliki kemampuan tinggi. Sehingga indikator tersebut sudah terpenuhi bagi siswa yang kemampuannya tinggi.

Indikator soal nomor 4 : Menerapkan strategi untuk menyelesaikan suatu masalah matematika yang diberikan.

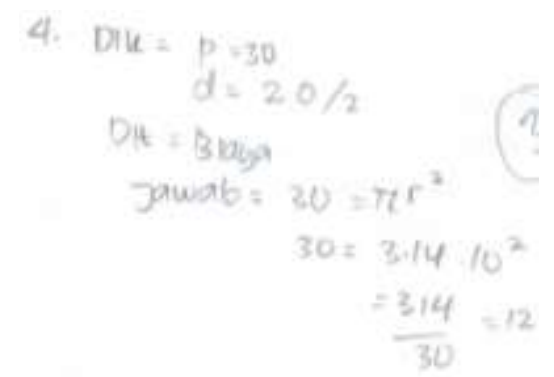

Gambar 5. Jawaban siswa yang salah 
Berdasarkan gambar 5 di atas, telihat bahwa siswa memiliki kemampuan rendah. Siswa tidak dapat menyelesaikan persoalan dengan strategi yang tepat. Kemampuan siswa yang rendah ini diakibatkan kurangnya penguasaan konsep-konsep dasar maupun konsep-konsep dari materi yang diujikan. Bagi siswa yang kemampuannya rendah mungkin persoalan ini akan dianggap sangat sulit untuk diselesaikan. Sehingga untuk indikator pada nomor 4 belum terpenuhi bagi siswa yang memiliki kemampuan rendah.

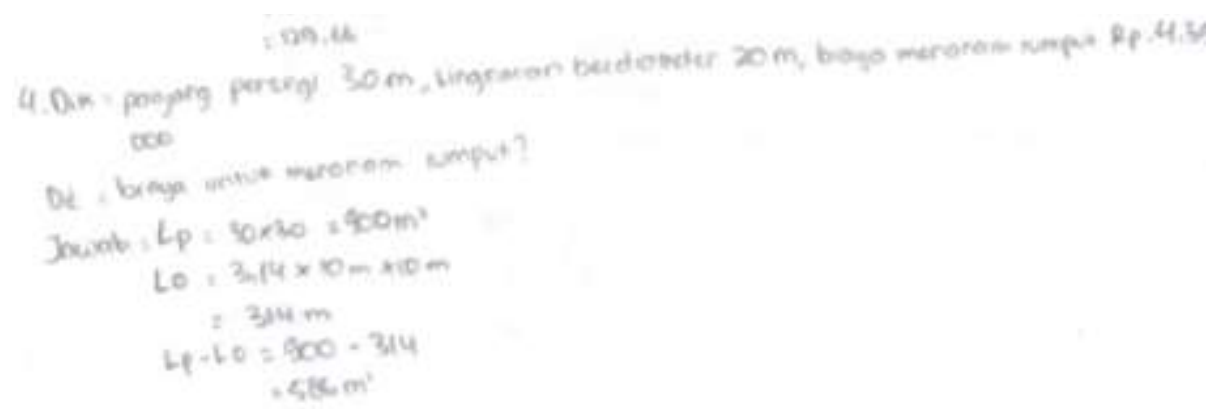

Gambar 6. Jawaban siswa yang benar

Berdasarkan gambar 6 di atas, untuk indikator tersebut sudah terpenuhi hanya saja kurang lengkap dalam menyelesaikan persoalan yang diberikan. Bagi siswa yang dapat menyelesaikan persoalan di atas sudah termasuk siswa yang memiliki kemampuan tinggi. Hanya saja siswa harus lebih teliti dalam menjawab soal tersebut. Siswa tersebut sudah menguasai konsep-konsep yang dalam mater yang diujikan. Sehingga untuk indikator pada soal nomor 4 sudah terpenuhi untuk siswa yang memiliki kemampuan tinggi.

\section{Pembahasan}

Hasil penelitian menunjukkan terdapat hubungan resiliensi terhadap kemampuan pemecahan masalah matematik siswa sebesar 0,649 dan 0,351 disebabkan oleh faktor lainnya. Menurut Newman (Hendriana et al., 2017) bahwa resiliensi memungkinkan siswa dapat mengatasi hambatan atau kesulitan dalam belajar matematik. (Maryam et al., 2018) mengatakan bahwa resiliensi matematik merupakan serangkaian sikap yang memberikan respons positif terhadap belajar matematika. Polya (Hendriana et al., 2017) mengemukakan bahwa pemecahan masalah adalah usaha yang dilakukan untuk mencari jalan keluar dari suatu tujuan yang tidak mudah segera dicapai. Dapat dikatakan bahwa siswa yang memiliki resiliensi baik maka kemampuan pemecahan masalahnya pun akan baik.

Selajutnya hasil jawaban siswa yang memiliki kemampuan tinggi kesulitan yang dialami tidak terlalu signifikan jika dibandingkan dengan hasil jawaban siswa yang memliliki kemampuan rendah. Pada gambar 1, 3, dan 5 terlihat bahwa hasil jawaban siswa yang memiliki kemampuan rendah kesulitan dalam memahami masalah yang ada pada soal serta menentukan strategi untuk menyelesaikan permasalahan, hal ini disebabkan kurangnya pemahaman/penguasaan konsep pada materi yang diujikan serta siswa tidak dapat menyelesaikan permasalahan tersebut sesuai dengan prosedur penyelesaiannya. Kurangnya penguasaan konsep ini mengakibatkan siswa mengisi dengan rumus yang menurutnya tepat tanpa memikirkan jawabannya benar atau salah. Hal ini sejalan dengan penelitian yang dilakukan oleh Sanhadi, Mardiyana, \& Pramudya (2017) mengungkapkan bahwa siswa mengalami kesulitan menentukan strategi penyelesaian yang tepat karena belum tepat menjelaskan rencana penyelesaiannya. Selanjutnya, siswa mengalami kesulitan dalam melakukan prosedur matematika yang benar karena kesalahan konsep dalam pemecahan masalah. Penyebab kesulitannya adalah kurangnya pemahaman siswa pada materi yang diujikan. 


\section{KESIMPULAN}

Berdasarkan penelitian yang sudah dilakukan di kelas VIII I MTs Negeri Kota Cimahi dapat disimpulkan bahwa setelah dilakukan analisis terhadap jawaban siswa, terdapat kesulitankesulitan siswa dalam menyelesaikan soal pemecahan masalah karena rendahnya kemampuan pemecahan masalah siswa dan kurangnya pemahaman konsep-konsep dasar yang berkaitan dengan materi lingkaran. Indikator dari kemampuan pemecahan masalah dapat terpenuhi oleh siswa dengan kemampuan pemecahan masalah yang tinggi, serta terdapat hubungan yang signifikan antara resiliensi matematik terhadap kemampuan pemecahan masalah siswa.

\section{DAFTAR PUSTAKA}

Alifah, N., \& Aripin, U. (2018). Proses Berpikir Siswa SMP Dalam Memecahkan Masalah Matematik Ditinjau dari Gaya Kognitif Field Dependent dan Field Independent. JPMI (Jurnal Pembelajaran Matematika Inovatif), 1(4).

Amir, M. F. (2015). Pengaruh Pembelajaran Kontekstual Terhadap Kemampuan Pemecahan Masalah Matematika Siswa Sekolah Dasar, (2011), 34-42.

Basuki, N. R. (2012). Analisis Kesulitan Siswa SMK pada Materi Pokok Geometri dan Alternatif Pemecahannya, 97-104.

Bernard, M. (2014). Meningkatkan Kemampuan Penalaran Matemattik Siswa SMA Melalui Game Adobe Flash CS 4, 2, 205-213.

Bernard, M. (2015). Meningkatkan kemampuan komunikasi dan penalaran serta disposisi matematik siswa SMK dengan pendekatan kontekstual melalui game adobe flash cs 4.0. Jurnal Infinity, 4(2), 197-222.

Bernard, M., Nurmala, N., Mariam, S., \& Rustyani, N. (2018). Analisis Kemampuan Pemecahan Masalah Matematis Siswa SMP Kelas IX Pada Materi Bangun Datar. Supremum Journal of Mathematics Education, 2(1), 81.

Hendriana, H., Rohaeti, E. E., \& Sumarmo, U. (2017). Hard Skills dan Soft Skills Matematik Siswa. (N. F. Atif, Ed.). Bandung: PT Refika Aditama.

Hidayat, W., \& Sariningsih, R. (2018). Kemampuan Pemecahan Masalah Matematis dan Adversity Quotient Siswa SMP Melalui Pembelajaran Open Ended. JNPM (Jurnal Nasional Pendidikan Matematika), 2(1), 109-118.

Husna, Ikhsan, M., \& Fatimah, S. (2013). Peningkatan Kemampuan Pemecahan Masalah dan Komunikasi Matematis Siswa Sekolah Menengah Pertama Melalui Model Pembelajaran Kooperatif Tipe Think-Pair-Share (TPS), 1(April), 81-92.

Maryam, M. S., Nurdiawan, R., Hermawan, W., Purwasih, R., \& Rohaeti, E. E. (2018). ANALISIS KEMAMPUAN PENALARAN MATEMATIS DAN MATHEMATICAL RESILIENCE SISWA SMA. Jurnal Apotema, 4(1), 49.

Sanhadi, K. C. D., Mardiyana, \& Pramudya, I. (2017). Analisis Kesulitan Siswa Dalam Memecahkan Masalah Materi Program Linear Ditinjau Dari Kemampuan Memahami Bacaan Siswa Kelas XI SMA MTA Surakarta Tahun Pelajaran 2016 / 2017. Prosiding Seminar Matematika Dan Pendidikan Matematika FKIP UNS.

Sugiyono. (2015). Metode Penelitian Kombinasi (Mixed Methods). (Sutopo, Ed.). Bandung: ALFABETA, cv.

Sundayana, R. (2016). Kaitan antara Gaya Belajar, Kemandirian Belajar, dan Kemampuan Pemecahan Masalah Siswa SMP dalam Pelajaran Matematika. Jurnal Mosharafa, 5(2), 78. 